\title{
The influence of climate on air and precipitation chemistry over Europe and downscaling applications to future acidic deposition
}

\author{
Julie M. J ones ${ }^{1, *}$, Trevor D. Davies ${ }^{2}$ \\ ${ }^{1}$ Institute of Hydrophysics, G KSS, M ax-Planck-Strasse, 21502 G eesthacht, G ermany \\ ${ }^{2}$ School of Environmental Sciences, University of East Anglia, N orwich N R4 7TJ, United Kingdom
}

\begin{abstract}
Atmospheric circulations, and related climate conditions, exert a strong influence on the transport and ultimate deposition of atmospheric pollutants. One potential outcome of climate change is alteration of atmospheric circulation patterns. The first stage in the development of a downscaling methodology to assess the influence of these possible future atmospheric circulation changes on transport and deposition of atmospheric pollutants over Europe is described. Firstly, the main modes of regional-scale circulation over a domain covering the North Atlantic and Europe are determined using principal components analysis of sea level pressure patterns. To determine whether the principal components represent circulation types found in reality, and show realistic relationships with surface temperature and precipitation amount, they are compared to the Lamb Weather Types, Central England Temperature, and England and Wales Rainfall. There are statistically significant relationships between some of the principal components and aqueous and ambient pollutant concentrations at 5 selected stations from the European Monitoring and Evaluation Programme monitoring network. Although, for any one combination of principal component and pollutant variable, the level of explanation can be quite small, notwithstanding some levels of variance explained for individual combinations being up to $69 \%$ ( $45 \%$ for the winter season, described in detail here). Because the pollution climate at any one location is a function of many combinations of circulation/pollution relationships, despite the relatively small magnitude of variance explained for individual combinations in this study, the results confirm the utility of atmospheric circulation principal components in deriving downscaling relationships for surface pollution behaviour (via eventual multiple regressions, not reported in this paper), as well as giving further insight into the climatic influences on air and precipitation chemistry over Europe.
\end{abstract}

KEY WORDS: Acidic deposition - Air pollution - Downscaling - Synoptic climatology - Principal components analysis · Climate change

\section{INTRODUCTION}

Acidic deposition is the final stage in a chain of processes linking emission sources and atmospheric transport and transformation. Meteorology exerts a controlling influence in this chain. A number of synoptic climatological approaches have been used in attempts to embrace a range of the pertinent meteorological processes. Examples include the use of Lamb

*E-mail: jones@gkss.de
Weather Types (LWT) (Davies et al. 1986, 1991, O'H are $\&$ Wilby 1995), statistical clustering of meteorological variables (Sanchez et al. 1990, M cGregor \& Bamzelis 1995), and the grouping of airmass trajectories (Dorling et al. 1992, M oody et al. 1995). Such studies have demonstrated clear links between atmospheric circulation and the transport and deposition of acidifying compounds. An important implication is that climate change, with possible circulation changes, may lead to changes in the transport and deposition patterns of acidic species (Davies et al. 1986). 
The known links between atmospheric circulation patterns and surface climate variables have been used to produce possible future climate scenarios, on the regional scale, by the synoptic climatological classification of atmospheric circulations projected by general circulation models (GCMs) (e.g. Hewitson \& Crane 1992, Goodess \& Palutikof 1998). Such methods are now widely used (Hewitson \& Crane 1996, Wilby et al. 1998). Extension of such a 'downscaling' methodology to the issue of possible future acidic deposition is, therefore, quite logical, given the clear links between present acidic deposition patterns and atmospheric circulation. The objective of this work, as the first step in the production of possible future scenarios of acidic deposition, is to establish whether or not there are distinct relationships between pollutant concentrations and depositions and atmospheric circulation, using the downscaling techniques which have been applied to surface climate variables. If successful, this would then allow the first application of a downscaling technique to future acidic depositions, using the projections of future circulations from GCMs. This would complement the previous, different, approaches to the assessment of the possible influence of future climate change on acid deposition over Europe. Pitovranov (1988) used an analogue method to suggest changes in Grosswetterlagen frequency, and the consequent effects on pollutant transport. Smith (1992) considered the combined effects of possible future emission changes, and possible changes in precipitation regimes, and Alcamo et al. (1995) linked integrated assessment models of climate change and acid deposition.

This study uses principal components analysis (PCA) to determine the main modes of spatial variation in atmospheric circulation over the North Atlantic and Europe. Comparisons are then made with an established climatological classification (LWT), and surface observation (Central England Temperature [CET] and England and Wales Rainfall [EWR]), to confirm the physical sense of the principal components (PCs) of the circulation. Relationships are then established between the PCs and observed pollutant concentrations and depositions at 5 stations in the European Monitoring and Evaluation Programme (EMEP) monitoring network (J ones 1997, J ones \& Davies 1998, unpubl.). This is an important step since it will determine if the links between the circulation PCs and the pollution are strong enough for application to future scenario studies. Moreover, the physical reality of the relationships may be assessed through comparison with circulation/pollution relationships over the same study region determined by a different approach (e.g. Dorling et al. 1992).

The length of the data series used for this work was limited by the availability of the EMEP data. At the time analysis was begun, only about $10 \mathrm{yr}$ of continuous data with acceptable levels of missing data for the variables considered were available.

\section{PRIN CIPAL COM PONENTS ANALYSIS OF ATMOSPHERIC CIRCULATION}

The United Kingdom M eteorological Office (UKM O) northern hemisphere $5^{\circ}$ latitude by $10^{\circ}$ longitude gridded mean sea level pressure dataset was used (I ones 1987). Analysis was undertaken on a daily basis for the 4 standard meteorological seasons, for the region $40^{\circ} \mathrm{E}-40^{\circ} \mathrm{W}, 30-80^{\circ} \mathrm{N}$, and for the period 1982 to 1991. This period corresponded to the time of greatest EM EP data availability for this study. Orthogonally rotated PCA was applied to the data, using the varimax rotation (von Storch \& Zwiers 1999). Opinions differ on whether or not to use rotation (Richman 1986, J olliffe 1987). Because interpretation of patterns is regarded as more straightforward with rotation (Yarnal 1993), it was used in this study. Components with eigenvalues greater than 1 were retained for rotation (i.e. only components which explained more variance than the original variables), a criterion used by Horel (1981) and Villalba et al. (1997). This led to between 14 and 16 components in each season being retained for rotation. The retention of a relatively large number was desirable, since a characteristic of acidic deposition is that it may be episodic (i.e. a large proportion of annual deposition at a site may occur under relatively infrequent meteorological conditions; Smith \& Hunt 1978). In extreme cases, in some locations, up to one-third of the total annual deposition of acidic species may occur in 1 day (Davies et al. 1992). Thus, although much deposition may be expected under frequently occurring conditions, inclusion of the more uncommon synoptic types increases the probability that a greater proportion of deposition may be accounted for by the components. Thus components which explain only a few percent of the total variance have been retained. J olliffe (1982) suggests that PCs with smaller eigenvalues can be important in PC regression. The rationale that PCA identifies the most frequent modes of variance in a dataset naturally means that perhaps very infrequent conditions important to deposition at the stations may not be captured by the classification.

There has been some discussion as to which PC retention rules to use. North et al. (1982) suggest that if the sampling error of a particular eigenvalue is equal or larger to the spacing between it and the neighbouring eigenvalue then the sampling error of the empirical orthogonal function (EOF) is comparable to the size of the neighbouring EOF. Von Storch (1995) suggests that this approach is more objective from a 
statistical point of view. Kidson (1988) uses a combination of this method and the 'scree test'. The latter involves plotting the eigenvalue against PC number. A break in slope is then identified, after which the eigenvalues of the following components, which represent uncorrelated noise, should decay exponentially. This methodology has the advantage of being easy to understand, and is relatively conservative. It involves however a subjective judgement about the location of the break in the plotted curve. The results in the following sections, of relationships between the components and CET, EWR, the LWT and with the EMEP station data, support the physical reality of the components retained.

The component loadings are shown in Figs. 1 (winter) \& 2 (summer). The maps show the contribution of the variable at each grid-point to each PC. The values in parentheses are the percentage variance explained by each component. In the winter PC3, explaining $9.8 \%$ of the variance, for example, the highest variance
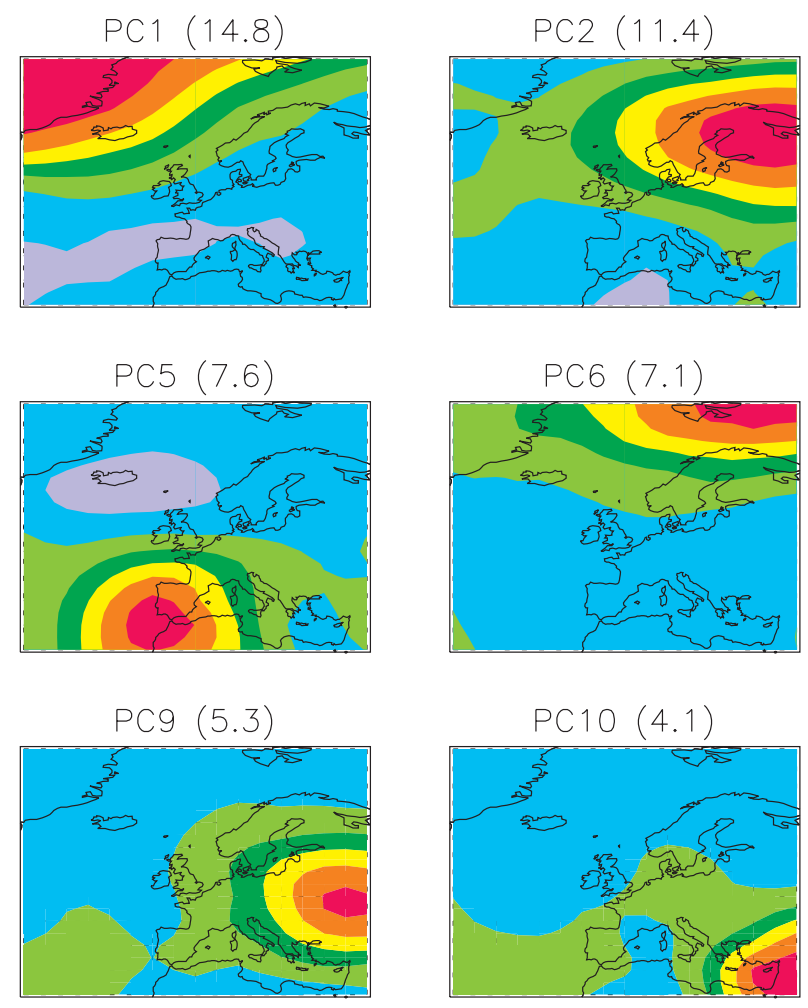

PC13 (2.2)
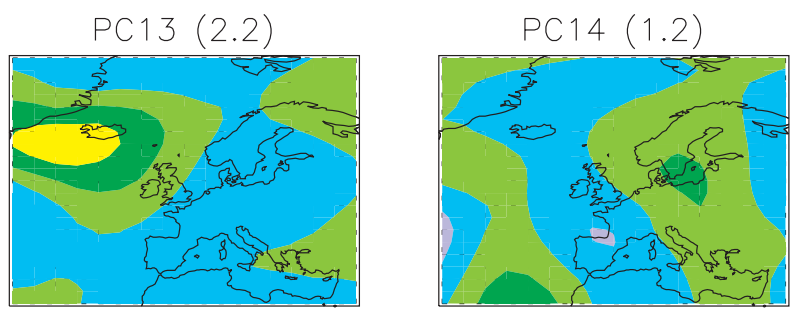

occurs in the grid points over the southern UK. It can be seen that the majority of the patterns are common between these 2 seasons, as in spring and autumn (not shown), although there are some differences in the ordering. For example, the PC6 map for winter (Fig. 1) is clearly the equivalent to that of $\mathrm{PC} 3$ in summer (Fig. 2).

For each time-step of the analysis a score for each PC is obtained, which represents the strength of a PC weight on a particular day. Interpretation of the PC patterns can be aided by the construction of composite circulation plots. Figs. 3 (winter) \& 4 (summer) show the mean pressure pattern of those days with component scores of more than twice the standard deviation (positive and negative) from the mean value. A greater number of composites are shown for winter as these are referred to later. These composites reveal that high positive scores correspond to high pressure at the centre of maximum variance, and large negative scores correspond to low pressure. Taking winter PC 3 as an
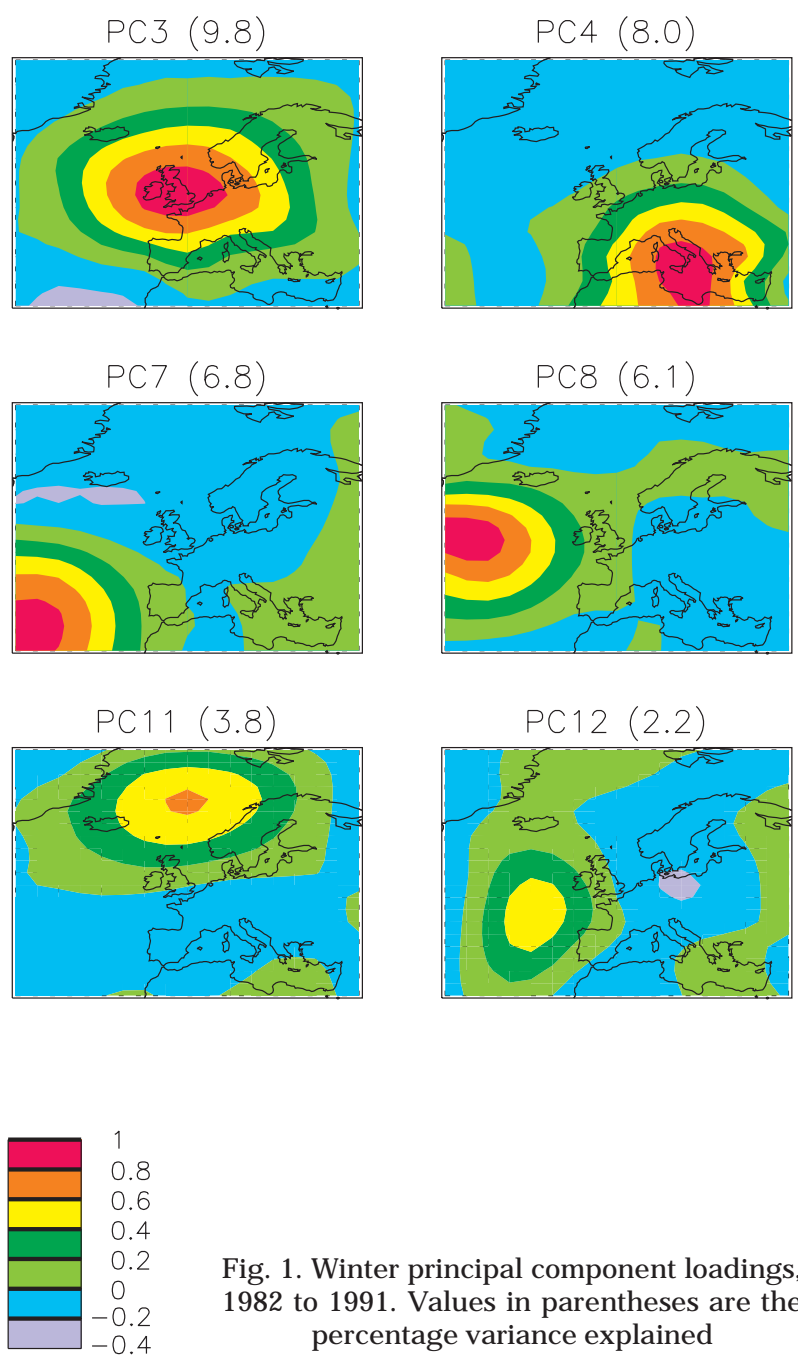

Fig. 1. Winter principal component loadings, 1982 to 1991 . Values in parentheses are the percentage variance explained 

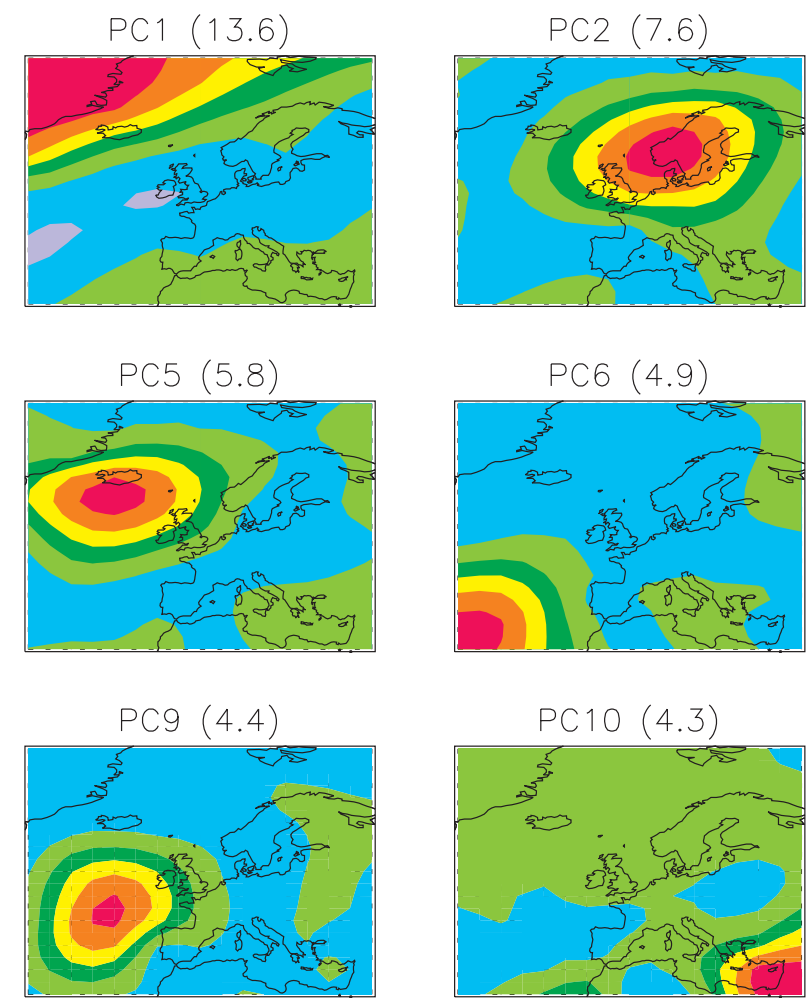

\section{PC13 (3.8)}

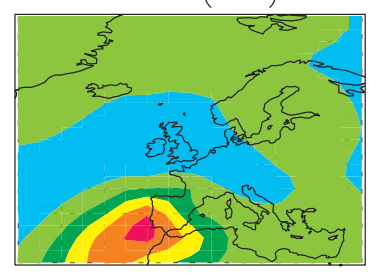

Fig. 2. Summer principal component loadings, 1982 to 1991 . Values in parentheses are the percentage variance explained

example again, the composite map for high positive score days shows an anticyclone centred on the region of maximum variance (Fig. 3). Similarly, the composite for the days of large negative scores reveals low pressure in this region. For brevity, hereafter, 'high scores' refer to high positive scores, and 'low scores' to large negative scores.

As previously indicated, the majority of patterns are common to all 4 seasons. The first component in all seasons represents variation in the strength of the zonal circulation. High pressure over Greenland and low pressure to the north of Scandinavia on high score days give a weakened zonal circulation (see PC1 in Figs. $3 \& 4$ ). Conversely, low scores indicate a strength-
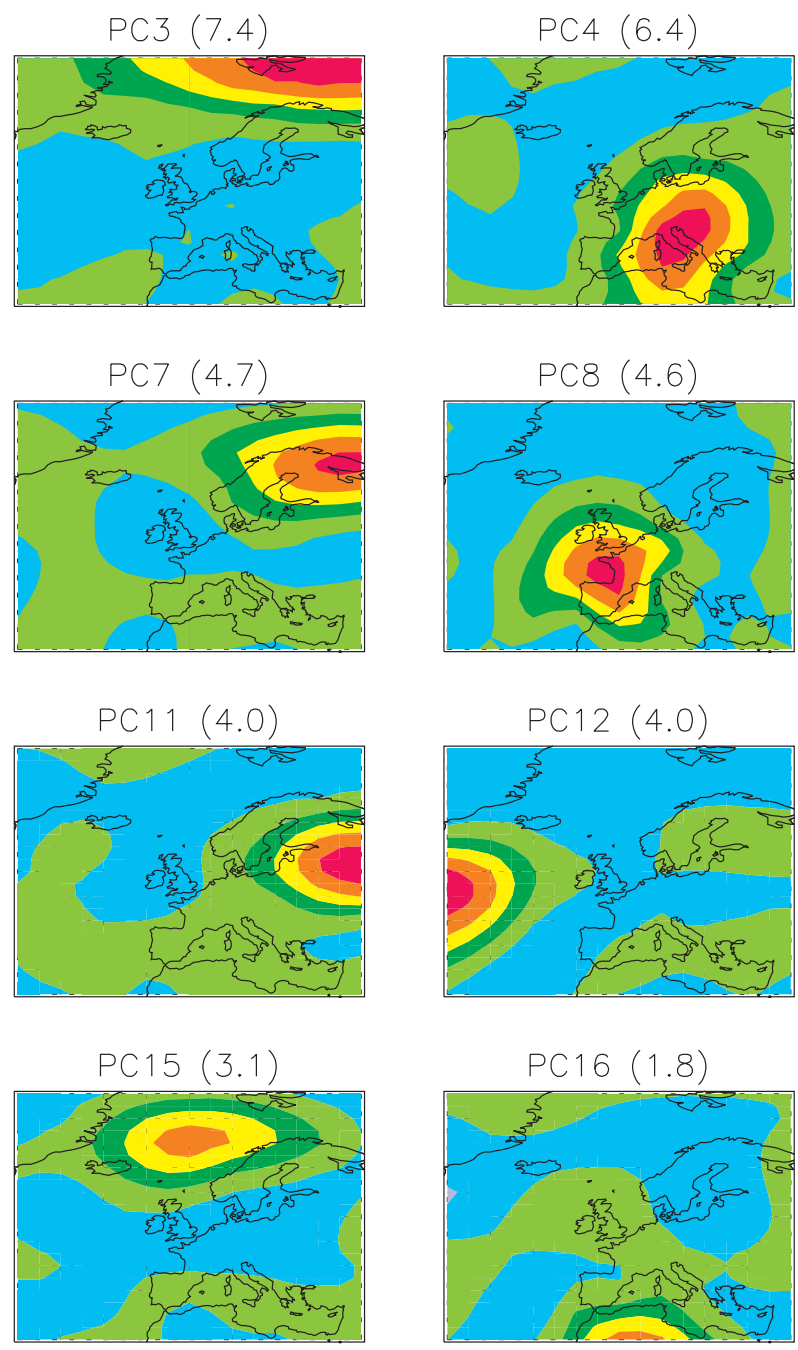

ening of flow with low pressure to the north of the domain, over Greenland, and high pressure to the south. In summer, this low pressure area is further north, reflecting the northward movement of the northern hemisphere storm tracks, with a ridge of high pressure extending from the southwest of the domain into northwest Europe (compare Fig. 4 with Fig. 3). A nother common pattern is a centre in the northeast of the domain (winter PC6, Fig. 1; summer PC3, Fig. 2). This component represents changes in the location of the north Atlantic storm track. On high score days of winter PC6 (Fig. 3), pressure is high over the Barents Sea and depressions are deflected southwards over northern Europe. In the opposite phase, pressure is low in this region as depressions travel to the north of high pressure over Europe.

Further discussion, and interpretation, of the PC patterns, in climatological terms, will be restricted to a comparison with the LWT (below). This is because the purpose of this paper is to establish links with pollutant 

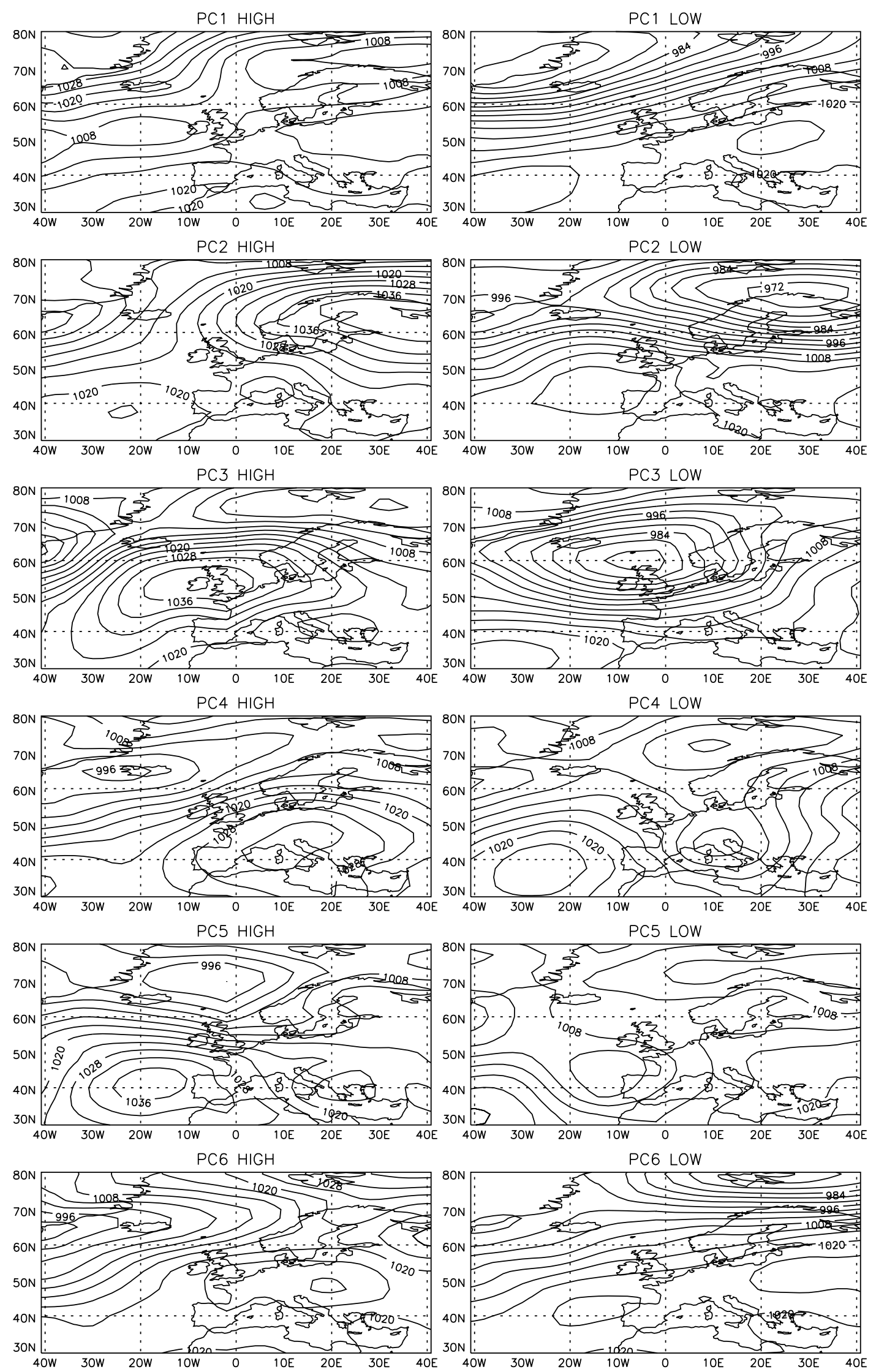

Fig. 3 (Above and on the following 2 pages). Winter mean sea level pressure composites for days with component scores $>2.0$ (high) and <-2.0 (low), 1982 to 1991 

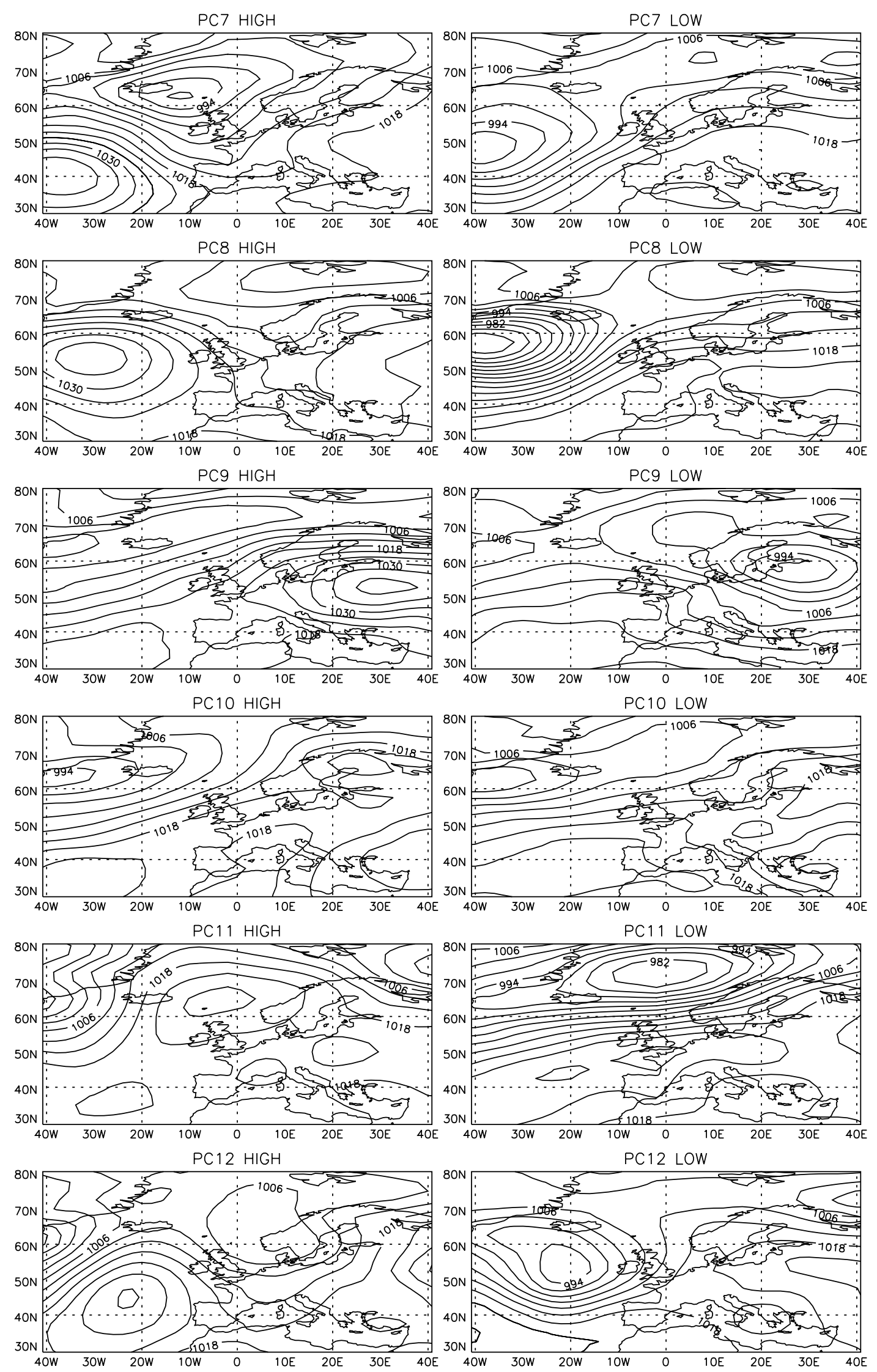

Fig. 3. (continued) 

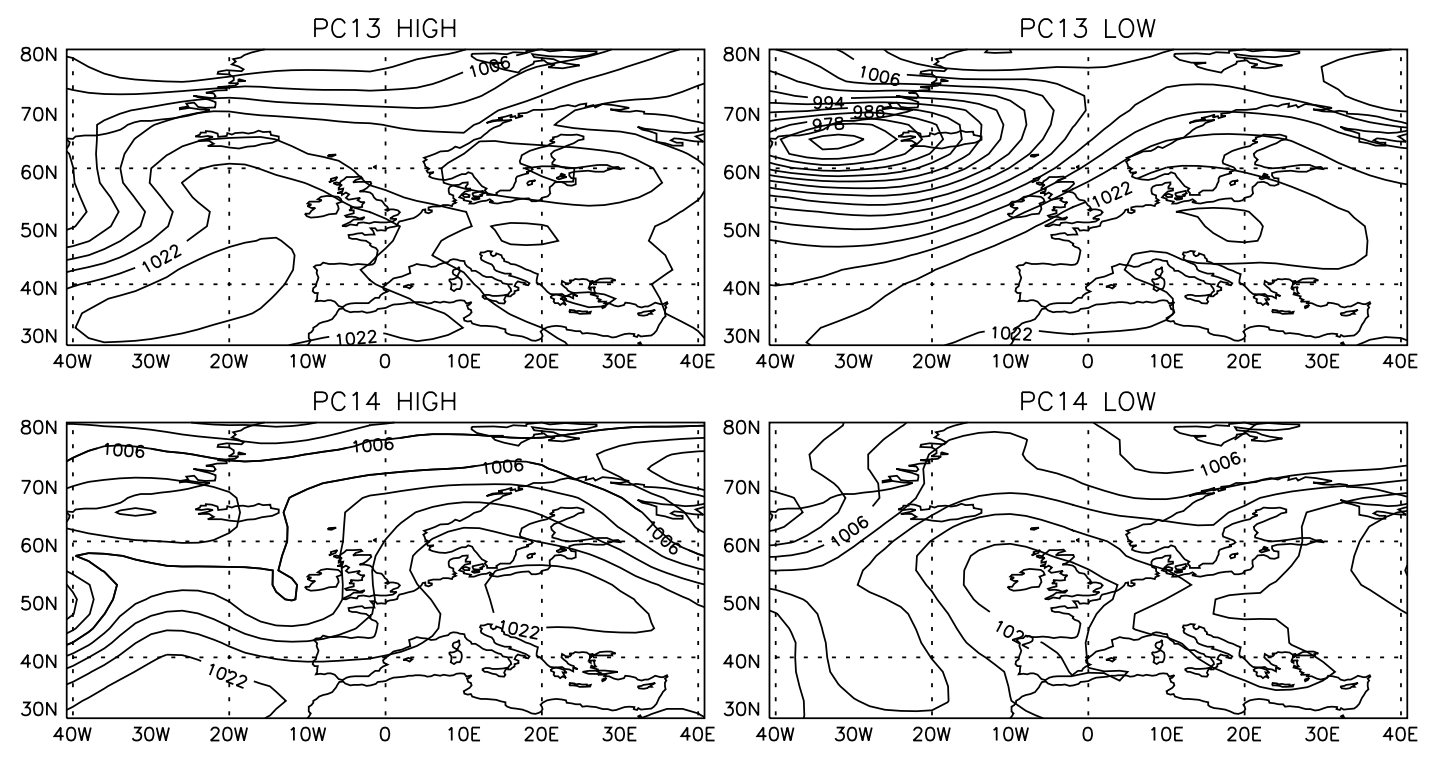

Fig. 3. (continued)

concentrations and deposition, and the sensible physical interpretation of the PCs on the European scale, in all 4 seasons, has been established elsewhere (J ones 1997). However, given the clear utility of the LWT for the study of acidic deposition in the UK (Davies et al. 1991), an examination of how clearly the PCA, at the European/North Atlantic scale, discriminates the circulation patterns on the smaller scale will be valuable.

\section{RELATIONSHIPS BETWEEN PRINCIPAL COM PONENTS AND LAMB WEATHER TYPES}

The LWT represent a manual daily synoptic classification for the British Isles (Lamb 1972), i.e. the judgement of the analyst is used to categorise the circulation by inspection and identification of the most frequent modes of atmospheric variability according to predetermined criteria. They are based on the surface airflow characteristics over the region $50-60^{\circ} \mathrm{N}$, $10^{\circ} \mathrm{W}-2^{\circ} \mathrm{E}$. There are 8 directional types, an anticyclonic type and a cyclonic type which together with hybrid types and unclassifiable situations give a total of 27 circulation types. The direction refers to the overall movement of synoptic systems and to the airflow direction over the British Isles.

Correlations were calculated between monthly frequencies of the LWT and monthly means of the component scores. This was done for the anticyclonic and cyclonic types, and for each of the 8 directional types. The cyclonic types were also summed with all the cyclonic hybrid types (e.g. cyclonic westerly + cyclonic southwesterly $+\ldots$ ) to give a cyclonic composite (CC) class. Similarly, anticyclonic types were summed together with anticyclonic hybrid types to give an anticyclonic composite (AC) class. Tables $1 \& 2$ show the values of the correlation coefficients for winter and summer, respectively. Significant positive (negative) correlations indicate high frequencies of a particular LWT in months with a high positive (negative) score. To use the example of winter PC3 (a centre over the British Isles) again, here there are significant negative correlations with cyclonic and CC classes (Table 1), and a significant positive correlation with the AC class. The composite plots show a cyclone over this region on low score days and an anticyclone on high score days (Fig. 3).

The northward shift in the zone of westerly flow, with anticyclonic cover over the North Atlantic and Northwest Europe (compare PC1 in Figs. $3 \& 4$ ) is reflected by the strong correlations with anticyclonic and AC types (Table 2). In summer, PC3 (the component representing variations in the location of the storm track, as described above) shows a significant positive relationship with cyclonic and CC types, and a significant negative relationship with anticyclonic and AC types (Table 2). Thus, as expected, a high frequency of cyclonic LWT occurs in months with high pressure to the northeast, because of the southward deflection of Atlantic cyclones, whereas high pressure extending over Europe is reflected in the negative relationship between PC 3 and anticyclonic and AC types. Although further examples will not be discussed in this paper, inspection of Tables $1 \& 2$ indicates that most components are significantly correlated with at least 1 LWT. Results are similar for spring and autumn (not shown here-see J ones 1997), with correlation 

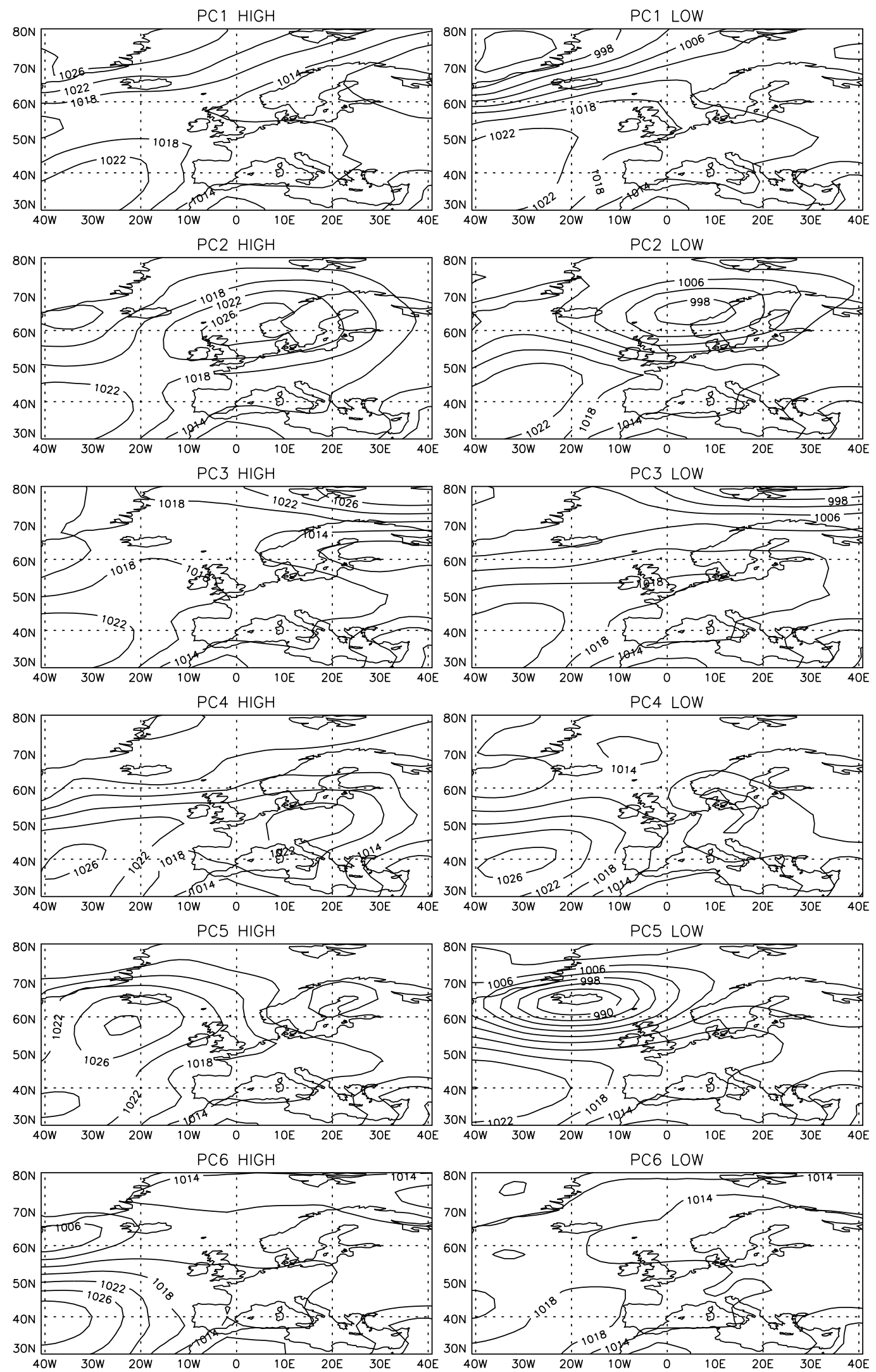

Fig. 4. Summer mean sea level pressure composites for days with component scores $>2.0$ (high) and <-2.0 (low), 1982 to 1991 
Table 1. Winter correlations between monthly mean component scores and monthly frequencies of the Lamb Weather Types. Values in bold are statistically significant at the $5 \%$ level. $n=27$. $A=$ anticyclonic, $C=$ cyclonic, $N E=$ northeasterly, $E=$ easterly, $\mathrm{S}=$ southerly, SW = southwesterly, $\mathrm{W}=$ westerly, $\mathrm{NW}=$ northwesterly, $\mathrm{N}=$ northerly, $\mathrm{AC}=$ anticyclonic composite, CC = cyclonic composite

\begin{tabular}{|c|c|c|c|c|c|c|c|c|c|c|c|c|}
\hline & A & C & $\mathrm{NE}$ & E & SE & S & SW & W & NW & $\mathrm{N}$ & AC & $\mathrm{CC}$ \\
\hline PC1 & 0.13 & -0.12 & 0.52 & 0.52 & 0.37 & -0.32 & -0.21 & -0.49 & -0.10 & 0.17 & 0.18 & -0.40 \\
\hline PC2 & 0.27 & -0.08 & 0.06 & 0.56 & -0.04 & -0.03 & -0.33 & -0.45 & -0.22 & 0.20 & 0.17 & -0.05 \\
\hline PC3 & 0.36 & -0.81 & -0.09 & 0.31 & 0.02 & -0.07 & -0.20 & -0.08 & 0.04 & -0.04 & 0.58 & -0.78 \\
\hline PC4 & -0.20 & -0.17 & -0.44 & -0.39 & -0.07 & 0.38 & 0.45 & 0.42 & 0.17 & -0.28 & -0.23 & -0.14 \\
\hline PC5 & -0.57 & 0.06 & -0.19 & -0.37 & -0.59 & 0.03 & 0.16 & 0.74 & 0.53 & -0.12 & -0.45 & 0.18 \\
\hline PC6 & -0.05 & -0.03 & 0.21 & 0.22 & 0.07 & 0.13 & 0.21 & -0.30 & -0.19 & 0.35 & -0.07 & -0.01 \\
\hline PC7 & -0.62 & 0.32 & -0.01 & -0.06 & -0.31 & 0.05 & 0.06 & 0.51 & 0.25 & -0.05 & -0.69 & 0.47 \\
\hline PC8 & 0.10 & -0.18 & -0.31 & -0.13 & -0.28 & -0.37 & -0.53 & 0.25 & 0.43 & 0.44 & 0.20 & -0.05 \\
\hline PC9 & -0.09 & 0.23 & 0.06 & -0.16 & -0.02 & 0.45 & 0.25 & -0.23 & -0.45 & -0.04 & -0.10 & 0.25 \\
\hline PC10 & -0.15 & 0.10 & -0.16 & -0.43 & -0.12 & 0.22 & 0.11 & 0.40 & 0.10 & -0.21 & -0.14 & 0.13 \\
\hline PCIl & 0.24 & -0.07 & 0.37 & 0.39 & 0.18 & -0.23 & -0.28 & -0.38 & -0.10 & 0.04 & 0.26 & -0.05 \\
\hline $\mathrm{PC} 12$ & 0.04 & -0.10 & -0.23 & -0.38 & -0.34 & 0.03 & -0.21 & 0.24 & 0.30 & 0.33 & 0.14 & -0.08 \\
\hline PC13 & 0.13 & -0.11 & 0.33 & 0.47 & 0.19 & -0.02 & -0.08 & -0.35 & -0.24 & 0.21 & 0.10 & -0.13 \\
\hline PC14 & -0.06 & -0.20 & 0.35 & 0.15 & 0.30 & 0.14 & 0.01 & -0.05 & -0.02 & -0.21 & -0.04 & -0.23 \\
\hline
\end{tabular}

coefficients attaining values of up to \pm 0.83 . An interesting feature is that, although the LWT classification is based on the British Isles, some remote centres of variation still show associations, because they are related with distinct flow directions over the Isles. Winter PC4, for example, is a centre in the eastern M editerranean (Fig. 1). Southwesterly flow over the British Isles, around an anticyclone over central/southern Europe on high score days (Fig. 3) is reflected in positive correlations with westerly and southwesterly LWT (Table 1). When a centre of variation is further west, as in the case of winter PC5, there is a significant correlation with southeasterly LWT (Table 1), due to flow around the northern flank of a cyclone situated to the southwest of the British Isles (Fig. 3).

\section{RELATIONSHIPS BETWEEN PRINCIPAL COMPONENTS AND THE CENTRAL ENGLAND TEMPERATURE AND ENGLAND AND WALES RAIN FALL SERIES}

A nother way of confirming the physical sense of the components is to examine their relationships with climatic variables. The datasets chosen for this analysis are the CET and EWR. The latter series is particularly pertinent because of the importance of precipitation as a deposition mechanism for acidic species. The CET was constructed on a monthly time scale by Manley (1974) for the period 1659 to 1973 . This was updated to 1992 and constructed on a daily time scale by Parker et al. (1992). The EWR is also an areal-average of a network of sites

Table 2. Summer correlations between monthly mean component scores and monthly frequencies of the Lamb Weather Types (abbreviations explained in Table 1). Values in bold are statistically significant at the $5 \%$ level. $n=30$

\begin{tabular}{|c|c|c|c|c|c|c|c|c|c|c|c|c|}
\hline & A & C & $\mathrm{NE}$ & E & SE & S & SW & W & NW & $\mathrm{N}$ & AC & CC \\
\hline PC1 & -0.67 & 0.58 & 0.20 & -0.01 & 0.24 & 0.05 & -0.01 & -0.03 & -0.12 & 0.47 & -0.70 & 0.57 \\
\hline PC2 & 0.74 & -0.59 & -0.17 & 0.45 & -0.02 & 0.09 & -0.50 & -0.40 & 0.21 & -0.28 & 0.75 & -0.62 \\
\hline PC3 & -0.47 & 0.48 & -0.08 & -0.13 & -0.10 & -0.06 & 0.21 & 0.18 & -0.15 & 0.25 & -0.50 & 0.42 \\
\hline PC4 & 0.07 & -0.14 & -0.31 & -0.25 & -0.07 & 0.03 & -0.17 & 0.16 & 0.45 & -0.19 & 0.13 & -0.17 \\
\hline PC5 & 0.27 & 0.17 & 0.32 & 0.13 & -0.08 & -0.04 & -0.50 & -0.72 & 0.13 & 0.46 & 0.16 & 0.06 \\
\hline PC6 & 0.15 & 0.07 & 0.10 & 0.06 & 0.01 & -0.28 & -0.24 & -0.11 & 0.19 & -0.36 & 0.13 & 0.08 \\
\hline PC7 & -0.25 & 0.31 & 0.10 & 0.04 & -0.39 & 0.13 & -0.16 & 0.02 & -0.24 & 0.31 & -0.24 & 0.27 \\
\hline PC8 & 0.14 & -0.13 & -0.14 & -0.21 & 0.20 & 0.25 & -0.26 & 0.17 & 0.46 & -0.19 & 0.11 & -0.21 \\
\hline PC9 & 0.37 & -0.57 & 0.12 & -0.35 & -0.48 & -0.08 & -0.09 & 0.16 & 0.51 & -0.05 & 0.43 & -0.48 \\
\hline PC10 & -0.12 & 0.11 & 0.30 & 0.04 & -0.15 & 0.20 & -0.25 & -0.36 & 0.03 & 0.47 & -0.15 & 0.09 \\
\hline PCll & -0.13 & 0.18 & -0.35 & 0.14 & 0.20 & -0.02 & -0.04 & 0.08 & -0.04 & -0.02 & -0.22 & 0.21 \\
\hline PC 12 & 0.21 & -0.09 & -0.11 & -0.15 & -0.05 & -0.13 & -0.19 & -0.13 & 0.10 & 0.02 & 0.19 & -0.06 \\
\hline PC13 & -0.27 & 0.51 & -0.27 & 0.13 & 0.22 & -0.15 & -0.15 & -0.22 & 0.10 & -0.04 & -0.37 & 0.49 \\
\hline PC14 & 0.03 & -0.09 & -0.27 & -0.30 & 0.22 & -0.02 & -0.01 & 0.28 & 0.34 & -0.10 & 0.02 & -0.17 \\
\hline PC15 & -0.15 & 0.13 & 0.31 & -0.10 & -0.04 & 0.16 & 0.03 & -0.32 & 0.03 & 0.56 & -0.25 & 0.19 \\
\hline PC16 & 0.14 & -0.35 & -0.52 & -0.02 & 0.17 & 0.15 & 0.04 & 0.02 & 0.03 & -0.05 & 0.30 & -0.40 \\
\hline
\end{tabular}


Table 3. Correlation coefficients between the observed components and the Central England Temperature (CET) and England and Wales Rainfall (EWR). Values in bold are statistically significant at the $5 \%$ level. $n=$ number of cases

\begin{tabular}{|lrrrr|}
\hline & \multicolumn{2}{c}{ Winter } & \multicolumn{2}{c|}{ Summer } \\
& CET & EWR & \multicolumn{1}{c}{ CET } & \multicolumn{1}{c}{ EWR } \\
\hline PC1 & $\mathbf{- 0 . 4 7}$ & -0.31 & $\mathbf{- 0 . 5 2}$ & $\mathbf{0 . 6 8}$ \\
PC2 & $\mathbf{- 0 . 6 2}$ & $-\mathbf{0 . 4 0}$ & $\mathbf{0 . 5 6}$ & $\mathbf{- 0 . 6 4}$ \\
PC3 & -0.26 & $\mathbf{- 0 . 7 9}$ & -0.35 & $\mathbf{0 . 4 7}$ \\
PC4 & $\mathbf{0 . 5 7}$ & 0.22 & 0.28 & -0.24 \\
PC5 & $\mathbf{0 . 3 9}$ & 0.22 & -0.19 & -0.09 \\
PC6 & -0.21 & -0.16 & 0.10 & -0.26 \\
PC7 & 0.14 & 0.35 & -0.27 & 0.12 \\
PC8 & -0.09 & -0.25 & 0.08 & -0.26 \\
PC9 & 0.04 & -0.03 & 0.28 & $-\mathbf{0 . 6 0}$ \\
PC10 & 0.21 & 0.28 & $-\mathbf{0 . 5 3}$ & 0.01 \\
PC11 & $-\mathbf{0 . 4 9}$ & -0.26 & 0.01 & 0.20 \\
PC12 & 0.11 & -0.17 & 0.12 & -0.01 \\
PC13 & $\mathbf{- 0 . 4 7}$ & -0.21 & -0.21 & 0.35 \\
PC14 & -0.22 & -0.01 & 0.26 & 0.01 \\
PC15 & & & $-\mathbf{0 . 4 3}$ & 0.34 \\
PC16 & & & $\mathbf{0 . 3 7}$ & -0.33 \\
& & & & \\
n & 27 & 27 & 30 & 30 \\
\hline
\end{tabular}

over England and Wales, and covers the period 1766 to present (Wigley \& J ones 1987).

Correlation coefficients have been calculated between monthly mean component scores and monthly values for the CET and EWR. Table 3 shows the correlation coefficients for winter and summer. Significant positive (negative) values indicate low (high) temperature/precipitation amounts with high (low) scores. The relationships with CET in winter are physically sensible, reflecting the land/sea temperature contrast present in this season. Higher temperatures are related to zonal flow, because of the relatively warm Atlantic Ocean, whereas more meridional flow is associated with lower temperature. PC1, for example is negatively correlated with CET, indicating warmer temperatures with low scores (westerly flow) and cooler conditions with high scores (northerly/northeasterly flow) (Fig. 3). The negative relationships between CET and PC 2, PC11 and PC13 (Table 3) identify the distinction between cool easterly flow from the relatively cold continent and warmer westerly flow from the Atlantic (Fig. 3). The components exhibiting significant correlations (both negative) with EWR in winter are PC2 and PC 3 (Table 3). The composite pressure patterns for low loadings (i.e. the pressure patterns associated with higher precipitation) indicate westerly flow, and a cyclone, over the British Isles, for these 2 PCs, respectively (Fig. 3). Both of these synoptic situations are well known for the occurrence of precipitation in this region (Barrow \& Hulme 1997).
During summer, higher temperatures under anticyclonic conditions are reflected in the negative relationship between CET and PC1, and the positive relationship with PC2 (Table 3). PC15, which is an Icelandic centre north of the British Isles (Fig. 2) is negatively correlated with CET (Table 3); high score days are associated with northerly flow, and thus with lower temperatures. Summer precipitation is also correlated with a number of components. The significant correlations with PC2, PC 3 and PC 9 are related to the location of cyclones. The negative correlation with PC2, for example, reflects the cyclone present during low score days. The positive correlation between PC 3 and EWR, for example, reflects the more southerly storm track associated with high loadings (Fig. 4). On low score days of this PC, pressure is low in the northeast of the domain due to cyclones taking a more northerly path around high pressure extending over Europe. On high score days, pressure in the northeast is high, thus cyclones would be expected to take a more southerly path through the Baltic. This PC, as explained above, is positively correlated with cyclonic and cyclonic composite LWT. There is also a strong positive correlation between PC 1 and EWR. The LWT analysis above revealed that high scores are associated with cyclonic LWT, as the composite map for low scores (Fig. 4) indicates that depressions would be steered on a more southerly track than under high score conditions.

These links between the PCs and CET and EWR values are adequately interpretable in physical terms, and so impart a reasonable level of confidence to embark on the next step: linkages with EMEP station observations.

\section{RELATION SHIPS BETWEEN PRINCIPAL COMPONENTS AND EMEP STATION DATA}

The locations of the chosen stations are shown in Fig. 5: Eskdalemuir, Scotland $\left(55^{\circ} 19^{\prime} \mathrm{N}, 3^{\circ} 12^{\prime} \mathrm{W}\right)$; Birkenes, Norway $\left(58^{\circ} 23^{\prime} \mathrm{N}, 8^{\circ} 15^{\prime} \mathrm{E}\right)$; Karvatn, Norway $\left(62^{\circ} 47^{\prime} \mathrm{N}, 8^{\circ} 53^{\prime} \mathrm{E}\right)$; La Hague, France $\left(49^{\circ} 37^{\prime} \mathrm{N}, 1^{\circ} 50^{\prime} \mathrm{W}\right)$; and K-puszta, Hungary $\left(46^{\circ} 58^{\prime} \mathrm{N}, 19^{\circ} 35^{\prime} \mathrm{E}\right)$. The aim was to choose sites with a wide geographical dispersion, although choice was limited by data availability, quality and completeness. A choice from southern European sites was not possible. An additional reason for the choice of the first 3 sites was to allow comparison of this method with previous work, as these were used in the study by Dorling (1992).

To assess the influence of precipitation amount and transport direction on air and precipitation chemistry at the sites, a correlation analysis was undertaken. Firstly, correlations were determined between compo- 
nent scores and daily and monthly values of the aqueous and gaseous variables, using data for the period 1982 to 1991 . The variables considered were aqueous non-sea salt sulphate $\left(\mathrm{SO}_{4(\mathrm{aq})}\right)$, aqueous ammonium $\left(\mathrm{NH}_{4(\mathrm{aq})}\right)$, aqueous nitrate $\left(\mathrm{NO}_{3(\mathrm{aq})}\right)$, sulphur dioxide gas $\left(\mathrm{SO}_{2(\mathrm{~g})}\right)$ and sulphate aerosol $\left(\mathrm{SO}_{4(\mathrm{a})}\right)$, and also aqueous hydrogen ion $\left(\mathrm{H}_{(\mathrm{aq})}^{+}\right)$for La Hague and K-puszta. Concentrations of aqueous and gaseous pollutants are inversely correlated with precipitation amount (Davies et al. 1992); in order to account for this, partial correlation analysis was undertaken, controlling for variations in the amount of precipitation.

Daily concentrations of acidic species in rainfall are known to be approximately lognormally distributed (RGAR 1990). To confirm this, when the analysis is stratified by

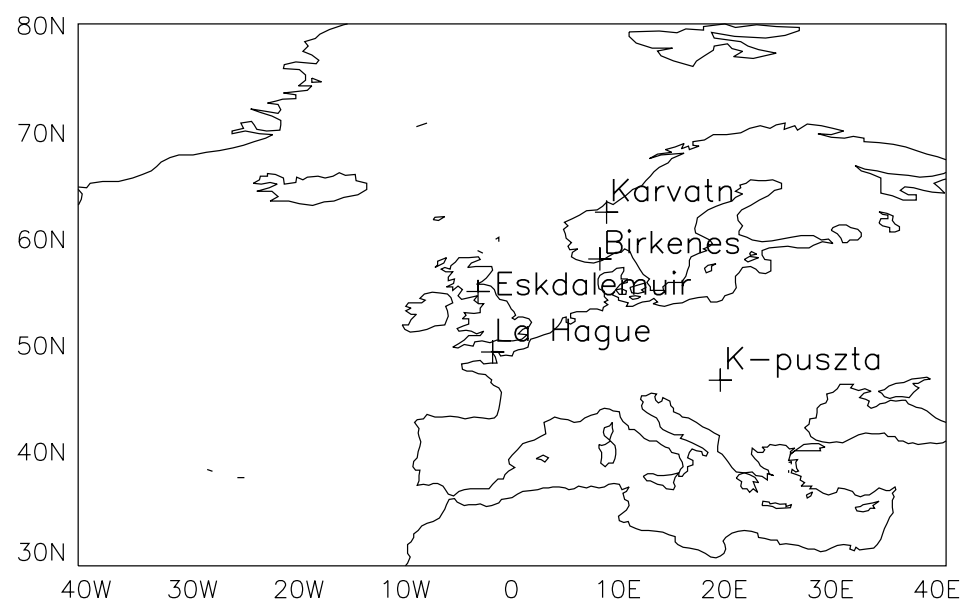

Fig. 5. Locations of the European Monitoring and Evaluation Programme (EMEP) stations used in this study

the flow direction for a particular component for both high score days and low score days comes from a strong pollution source in both cases, then a low correlation would be expected. Highest correlations would be expected when a component contrasts flow from 'clean' regions with flow from pollutant source regions, although other atmospheric conditions could also be important.

For each EMEP station, the characteristics of the pollution climate are described, and the relationships between the PCs and air and precipitation chemistry discussed for each season. A brief summary of the important relationships is also given. Due to space limitations, only winter results shall be discussed here. The results in the other 3 seasons are also robust, and reveal the same linkages between circulation and pollution climate at each of the stations (J ones 1997).

\subsection{Eskdalemuir}

where $\mathrm{n}$ is the original number of points correlated, $C D$ is the lag one autocorrelation coefficient for one series, and $C F$ the same for the other, and $n$ the corrected number of points. The monthly averaging of data removed the effect of serial correlation. To simplify the tables, the number of cases given for the daily data in Tables 4, 6, $8 \& 10$ is an average for all the PC s for that variable, as the autocorrelation of each PC is slightly different. However, the individual corrected number of cases was considered when marking significance levels.

Strong correlations of pollution data with PCs will occur only where the extremes of the components are associated with conditions which lead to differing impacts on pollutant concentrations. For example, where Scotland. Westerly flow from the North Atlantic therefore understandably exerts a strong influence on the pollution climate of the site. For example, Davies et al. (1992) examined the links between the zonal pressure gradient over the Northeast Atlantic and concentrations of aqueous sulphate, nitrate, ammonium and hydrogen ions over Europe. They detected a zone covering the UK, extending into northwestern Europe, where ion concentrations showed a strong inverse relationship with the pressure gradient. Transport from source regions of the southern UK and western Europe has also been found to affect concentrations and deposition at the site. Weakening of westerly airflow, and
Eskdalemuir is an upland station located in southern 
therefore enhanced southerly and/or easterly transport, was found to be related to high monthly aqueous sulphate concentrations at Eskdalemuir (Farmer et al. 1987).

The majority of the partial correlation coefficients between the PCs and daily station concentration data for winter (Table 4) are consistent with the known links, described above, contrasting the polluted flow from the pollution source regions of central and eastern Europe with the cleaner flow from the North Atlantic. For example, the transport direction to Eskdalemuir on low score days for PC2, centred over northern Eurasia, is westerly, and on high score days it is easterly (Fig. 3). Correlation coefficients between PC 2 and all the pollution variables are positive, implying increased concentrations with easterly flow from source regions of central Europe. Similarly, the positive correlations with PC 1 (significant for only aqueous sulphate and nitrate) imply increased concentrations with weakened zonal flow.

An interesting relationship is the negative correlation between all variables and PC5, centred in the western M editerranean (Fig. 1). It may appear that the centre is too far south to exert an influence on the polIution climate of Eskdalemuir, but the low score (high concentrations) composite map (Fig. 3) shows southeasterly flow to the UK around the eastern flank of low pressure centred off the northwest coast of Spain (Fig. 3).

A smaller number of significant relationships exist for the monthly correlations (Table 5). The positive relationship with PC2 remains for excess sulphate and nitrate concentrations (i.e. high concentrations with easterly flow).

Table 4. Eskdalemuir winter daily partial correlation coefficients. Values in bold are statistically significant at the $5 \%$ level. $\mathrm{n}=$ number of cases. Values adjusted for autocorrelation

\begin{tabular}{|c|c|c|c|c|c|}
\hline & $\mathrm{InSO}_{4(\mathrm{aq})}$ & $\operatorname{lnNH}_{4(\mathrm{aq})}$ & $\operatorname{lnN} \mathrm{N}_{3(\mathrm{aq})}$ & $\operatorname{lnSO}_{2(\mathrm{~g})}$ & $\operatorname{lnSO}_{4(a)}$ \\
\hline PC1 & 0.10 & 0.06 & 0.14 & 0.09 & -0.02 \\
\hline PC2 & 0.26 & 0.16 & 0.33 & 0.25 & 0.30 \\
\hline PC3 & 0.21 & 0.38 & 0.19 & 0.09 & 0.27 \\
\hline PC4 & -0.07 & -0.03 & -0.09 & -0.12 & 0.05 \\
\hline PC5 & -0.13 & -0.11 & -0.20 & -0.11 & -0.17 \\
\hline PC6 & 0.02 & -0.03 & -0.01 & 0.01 & -0.02 \\
\hline PC7 & 0.02 & 0.00 & -0.05 & -0.04 & -0.09 \\
\hline PC8 & -0.02 & 0.01 & -0.11 & -0.07 & -0.21 \\
\hline PC9 & 0.14 & 0.14 & 0.12 & 0.00 & 0.10 \\
\hline PC10 & 0.03 & -0.02 & 0.06 & 0.02 & 0.03 \\
\hline PC11 & 0.23 & 0.13 & 0.24 & 0.18 & 0.13 \\
\hline PC12 & -0.13 & -0.07 & -0.18 & -0.16 & -0.17 \\
\hline PC13 & -0.02 & -0.07 & 0.00 & -0.06 & -0.09 \\
\hline PC 14 & 0.08 & 0.11 & 0.09 & 0.14 & 0.09 \\
\hline$n$ & 270 & 270 & 260 & 190 & 180 \\
\hline
\end{tabular}

\subsection{Birkenes}

Birkenes is located in southern Norway, to the southeast of the Scandinavian mountain chain. Thus when flow is from the west and northwest much moisture has been removed over the mountains before the air reaches the site. The southwest tends to be the direction associated with the most precipitation at the site (Dorling \& Davies 1995), although easterly flow also brings precipitation. A frequent precipitation-bearing situation in autumn and winter is when the Atlantic Polar Front is displaced southwards, and a trough extends from Greenland to central Europe. The resulting southerly/southeasterly flow of Atlantic air to Scandinavia also picks up further moisture over the Baltic Sea, and is subjected to orographic uplifting when it reaches the Scandinavian mountains (J ohannessen 1970). Due to the location of the site away from local pollution sources, long range transport exerts a large influence on the pollution climatology of the site. The UK and eastern and central Europe have all been identified as dominant source regions (Berge 1988, A mundsen et al. 1992).

The positive daily correlation coefficients between all variables and PC2 and PC9 (Table 6) show that southerly and southeasterly flow to the site, around the southern edge of the Eurasian winter anticyclone (Fig. 3), is related to high concentrations for all variables. The negative correlations between concentrations of the aqueous variables and PC 13, centred over Iceland, imply that the UK is a source region of pollutants to the site, as the low score composite in Fig. 3 shows southwesterly flow from the UK, around low pressure to the west of Iceland. Likewise, southwest-

Table 5. Eskdalemuir winter monthly partial correlation coefficients. Values in bold are statistically significant at the 5\% level. $\mathrm{n}=$ number of cases

\begin{tabular}{|lcrrrr|}
\hline & $\operatorname{InSO}_{4(\mathrm{aq})}$ & \multicolumn{1}{l}{$\mathrm{InNH}_{4(\mathrm{aq})}$} & $\mathrm{InNO}_{3(\mathrm{aq})}$ & $\mathrm{InSO}_{2(\mathrm{~g})}$ & $\mathrm{InSO}_{4(\mathrm{a})}$ \\
\hline PC1 & 0.22 & 0.06 & 0.10 & 0.26 & -0.05 \\
PC2 & $\mathbf{0 . 4 0}$ & 0.28 & $\mathbf{0 . 4 9}$ & 0.36 & 0.18 \\
PC3 & 0.04 & 0.28 & -0.01 & -0.09 & 0.05 \\
PC4 & -0.31 & -0.14 & -0.24 & -0.27 & 0.25 \\
PC5 & 0.31 & 0.26 & 0.11 & 0.22 & -0.24 \\
PC6 & 0.13 & -0.05 & 0.00 & 0.02 & 0.01 \\
PC7 & 0.34 & 0.37 & 0.37 & 0.25 & 0.26 \\
PC8 & -0.04 & -0.15 & -0.22 & 0.09 & -0.51 \\
PC9 & 0.13 & 0.15 & 0.35 & -0.01 & 0.21 \\
PC10 & -0.08 & -0.09 & -0.01 & 0.20 & -0.10 \\
PC11 & 0.27 & -0.04 & 0.15 & 0.19 & -0.08 \\
PC12 & -0.17 & -0.13 & -0.23 & -0.05 & -0.37 \\
PC13 & 0.20 & 0.01 & 0.10 & -0.09 & 0.04 \\
PC14 & 0.14 & 0.18 & 0.19 & 0.22 & -0.05 \\
n & 27 & 27 & 27 & 27 & 27 \\
& & & & & \\
\hline
\end{tabular}


Table 6. Birkenes winter daily partial correlation coefficients. Values in bold are statistically significant at the $5 \%$ level. $\mathrm{n}=$ number of cases. Values adjusted for autocorrelation

\begin{tabular}{|c|c|c|c|c|c|}
\hline & $\mathrm{InSO}_{4(\mathrm{aq})}$ & $\operatorname{lnNH}_{4(\mathrm{aq})}$ & $\operatorname{lnNO}_{3(a q)}$ & $\mathrm{InSO}_{2(\mathrm{~g})}$ & $\operatorname{lnSO}_{4(\mathrm{a})}$ \\
\hline PC1 & 0.01 & -0.03 & 0.05 & -0.07 & -0.25 \\
\hline PC2 & 0.49 & 0.35 & 0.45 & 0.42 & 0.15 \\
\hline PC3 & -0.02 & 0.05 & -0.05 & -0.18 & -0.12 \\
\hline PC4 & 0.01 & 0.04 & -0.03 & 0.01 & 0.21 \\
\hline PC5 & -0.19 & -0.12 & -0.21 & -0.08 & 0.03 \\
\hline PC6 & 0.01 & 0.03 & 0.05 & 0.07 & -0.07 \\
\hline PC 7 & 0.02 & 0.10 & 0.03 & -0.04 & 0.00 \\
\hline PC 8 & -0.09 & -0.03 & -0.11 & -0.02 & -0.01 \\
\hline PC9 & 0.22 & 0.22 & 0.23 & 0.19 & 0.23 \\
\hline PC 10 & -0.05 & -0.04 & -0.06 & 0.02 & -0.09 \\
\hline PC11 & 0.20 & 0.04 & 0.24 & 0.07 & -0.08 \\
\hline PC 12 & 0.00 & -0.04 & -0.07 & 0.02 & -0.07 \\
\hline PC13 & -0.13 & -0.16 & -0.06 & -0.07 & -0.17 \\
\hline PC 14 & 0.16 & 0.18 & 0.17 & 0.05 & 0.18 \\
\hline$n$ & 240 & 230 & 240 & 175 & 155 \\
\hline
\end{tabular}

erly flow around the southern edge of a cyclone centred to the north of Scotland brings southwesterly flow to Birkenes in the low score phase of PC3 (Fig. 3), and is related to high concentrations of gas and aerosol.

On a monthly basis, Table 7 shows that southeasterly flow associated with high scores for the Eurasian centres of variation, $\mathrm{PC} 2$ and PC9, is the dominant control for aqueous sulphate, nitrate and $\mathrm{SO}_{2(\mathrm{~g})}$ concentrations. The flow patterns leading to high sulphate aerosol concentrations are those with southwesterly flow from the UK. For example, PC4, in the eastern Mediterranean (Fig. 1), is positively correlated with both monthly and daily sulphate aerosol concentrations. This PC contrasts southwesterly flow to Norway around the northern edge of high pressure over central Europe (high

Table 7. Birkenes winter monthly partial correlation coefficients. Values in bold are statistically significant at the $5 \%$ level. $\mathrm{n}=$ number of cases

\begin{tabular}{|lcrrrr|}
\hline & $\operatorname{InSO}_{4(\mathrm{aq})}$ & $\operatorname{InNH_{4(aq)}}$ & $\operatorname{InNO}_{3(\mathrm{aq})}$ & $\mathrm{InSO}_{2(\mathrm{~g})}$ & $\mathrm{InSO}_{4(\mathrm{a})}$ \\
\hline PC1 & 0.01 & -0.06 & 0.09 & 0.01 & $-\mathbf{0 . 5 1}$ \\
PC2 & $\mathbf{0 . 5 7}$ & 0.38 & $\mathbf{0 . 5 4}$ & $\mathbf{0 . 4 7}$ & -0.22 \\
PC3 & -0.21 & -0.07 & -0.20 & -0.02 & 0.27 \\
PC4 & 0.04 & 0.15 & -0.02 & 0.00 & $\mathbf{0 . 4 8}$ \\
PC5 & 0.02 & 0.03 & -0.19 & -0.03 & 0.07 \\
PC6 & -0.07 & -0.01 & 0.17 & 0.18 & -0.33 \\
PC7 & 0.23 & 0.28 & 0.33 & 0.11 & -0.04 \\
PC8 & 0.03 & -0.06 & -0.15 & -0.10 & 0.01 \\
PC9 & 0.30 & 0.23 & $\mathbf{0 . 4 1}$ & $\mathbf{0 . 4 1}$ & 0.06 \\
PC10 & 0.02 & 0.06 & -0.08 & 0.04 & 0.19 \\
PC11 & -0.17 & -0.10 & -0.14 & 0.07 & -0.09 \\
PC12 & 0.02 & -0.05 & -0.12 & 0.06 & 0.07 \\
PC13 & -0.29 & -0.21 & -0.07 & 0.05 & 0.02 \\
PC14 & -0.24 & -0.28 & -0.17 & -0.21 & 0.31 \\
n & 24 & 24 & 24 & 24 & 24 \\
\hline
\end{tabular}

scores and high concentrations) with northerly flow to the site (low scores and low concentrations). This is entirely consistent with an analysis of aerosol data at Birkenes by Pakkanen et al. (1996), who also identified the UK as an important source.

\subsection{Karvatn}

This station is the most remote of those considered in this study, situated on the west coast of N orway, to the northwest of the Scandinavian mountain chain.

Pollutants contained in flow from the southeast, an important source direction for the pollution climatology of Birkenes, are often removed when passing over the Scandinavian mountains (Dorling \& Davies 1995). Consequently, Karvatn experiences the lowest concentrations for all variables of the sites considered in this study, although pollutant concentrations at the site may still be relatively high from this direction when compared with concentrations associated with other flow directions. For example, PC2 is positively correlated with all pollutant concentrations (not statistically significant for $\mathrm{SO}_{2(g)}$ ) (Table 8), reflecting transport from major pollution source regions of central and eastern Europe. Gas and aerosol concentrations are positively related to $\mathrm{PC} 12$, a centre to the southwest of the UK (Fig. 1). The composite plot for high scores (Fig. 3) reveals a high pressure centre west of the Bay of Biscay, with a depression located over the North Sea, leading to southeasterly flow to Karvatn, without a long passage over land, which has a higher deposition velocity for gases and aerosols than does the sea surface. This circulation pattern was identified as being

Table 8. Karvatn winter daily partial concentration correlation coefficients. Values in bold are statistically significant at the $5 \%$ level. $\mathrm{n}=$ number of cases. Values adjusted for autocorrelation

\begin{tabular}{|c|c|c|c|c|c|}
\hline & $\mathrm{InSO}_{4(\mathrm{aq})}$ & $\operatorname{lnNH}_{4(\mathrm{aq})}$ & $\operatorname{lnNO}_{3(a q)}$ & $\mathrm{InSO}_{2(\mathrm{~g})}$ & $\mathrm{InSO}_{4(\mathrm{a})}$ \\
\hline PC1 & 0.15 & -0.12 & -0.13 & -0.09 & 0.17 \\
\hline PC2 & 0.20 & 0.13 & 0.24 & 0.20 & 0.33 \\
\hline PC3 & -0.11 & 0.03 & -0.20 & -0.40 & -0.19 \\
\hline PC 4 & -0.11 & 0.06 & 0.04 & -0.05 & -0.06 \\
\hline PC5 & -0.01 & 0.05 & 0.02 & 0.05 & 0.00 \\
\hline PC 6 & 0.14 & 0.09 & 0.04 & 0.18 & 0.17 \\
\hline PC 7 & -0.17 & 0.05 & 0.00 & 0.00 & -0.07 \\
\hline PC 8 & -0.03 & -0.06 & -0.13 & 0.08 & 0.04 \\
\hline PC9 & -0.07 & 0.07 & 0.08 & 0.10 & 0.04 \\
\hline PC 10 & -0.08 & 0.11 & 0.01 & 0.07 & 0.03 \\
\hline PC11 & 0.02 & -0.11 & -0.18 & 0.00 & 0.17 \\
\hline PC 12 & 0.10 & 0.01 & 0.02 & 0.16 & 0.12 \\
\hline PC13 & 0.14 & -0.07 & -0.03 & -0.05 & 0.04 \\
\hline PC 14 & -0.01 & 0.06 & -0.04 & -0.11 & -0.11 \\
\hline $\mathrm{n}$ & 270 & 215 & 238 & 85 & 160 \\
\hline
\end{tabular}


associated with above average pollutant concentrations at Karvatn by Dorling \& Davies (1995).

Similarly, typical low score days for PC3 (Figs. $1 \& 3$ ), which was negatively related to all variables except aqueous ammonium, show southeasterly flow to Karvatn, around a cyclone to the north of the UK. Thus increased concentrations are still contained in flow from source regions arising from this circulation type, in comparison to northwest flow from regions with few pollution sources. The precise location of a station in relation to fronts within such a system will also influence both where wet deposition will occur and acidic concentrations therein (Haagenson et al. 1985), although this cannot be determined from the current analysis.

Different source regions are implicated as important for nitrogen species and sulphur species. Flow from the UK is related to aqueous ammonium and nitrate (negative correlation with PC1), and aqueous nitrate (negative correlation with PC11). Conversely, sulphate aerosol concentrations are positively correlated with PC11, and aqueous sulphate and sulphate aerosol positively with $\mathrm{PC} 1$, indicating increased concentrations with weakened westerly/strengthened easterly flow.

Significant monthly correlations occur only with aqueous sulphate and sulphate aerosol (Table 9). The stronger relationships with these variables may be due to the remote location of the station from major pollution sources. Sulphate aerosol is a secondary pollutant, hence concentrations increase with distance from sources, and those of the primary pollutant, sulphur dioxide gas, decrease (RGAR 1990). The ratio of sulphate to nitrate in precipitation has been found to

Table 9. Karvatn monthly partial concentration correlation coefficients. Values in bold are statistically significant at the $5 \%$ level. $n=$ number of cases

\begin{tabular}{|lcrrrr|}
\hline & $\operatorname{InSO}_{4(\mathrm{aq})}$ & \multicolumn{1}{l}{$\operatorname{lnNH_{4(aq)}}$} & $\operatorname{InNO}_{3(\mathrm{aq})}$ & $\operatorname{InSO}_{2(\mathrm{~g})}$ & $\operatorname{InSO}_{4(\mathrm{a})}$ \\
\hline PC1 & $\mathbf{0 . 5 2}$ & -0.04 & 0.12 & -0.34 & $\mathbf{0 . 4 7}$ \\
PC2 & $\mathbf{0 . 5 4}$ & -0.35 & 0.05 & -0.07 & $\mathbf{0 . 6 7}$ \\
PC3 & 0.19 & 0.18 & -0.12 & -0.34 & 0.15 \\
PC4 & -0.34 & 0.21 & 0.24 & -0.12 & -0.29 \\
PC5 & -0.17 & -0.08 & 0.17 & 0.12 & -0.01 \\
PC6 & 0.20 & 0.01 & -0.15 & 0.14 & $\mathbf{0 . 5 1}$ \\
PC7 & -0.25 & 0.26 & 0.28 & 0.03 & -0.22 \\
PC8 & -0.07 & -0.33 & -0.22 & 0.08 & 0.08 \\
PC9 & -0.35 & -0.06 & -0.16 & 0.11 & -0.08 \\
PC10 & -0.19 & -0.18 & 0.03 & 0.18 & 0.06 \\
PC11 & 0.21 & -0.22 & -0.05 & -0.08 & 0.18 \\
PC12 & -0.14 & -0.31 & -0.30 & 0.35 & 0.08 \\
PC13 & 0.17 & 0.33 & -0.18 & -0.03 & 0.21 \\
PC14 & 0.07 & 0.15 & -0.11 & -0.29 & -0.17 \\
n & 27 & 27 & 27 & 27 & 27 \\
\hline
\end{tabular}

increase with increasing travel time of polluted air, as nitric acid is removed before sulphuric acid (Davies et al. 1988).

\subsection{K-puszta}

Pollutant concentrations are considerably higher at this site than the others, as it is located in a more densely populated and industrialised region. K-puszta is situated approximately $80 \mathrm{~km}$ southwest (downwind of the most common flow) of Budapest, the largest pollution source in the region. The city of Kecskemet is located $20 \mathrm{~km}$ from the site in a SSE direction, but there are significant local pollution sources in all directions. The region is also climatologically different from the western European sites. The station is located in the Hungarian Great Plain, in the Carpathian Basin, bounded to the northeast and east by the Carpathian Mountains, to the south by the Balkans, to the southwest by the Dinaric Alps and to the west by the Alps. This mountain barrier impedes flow of air into the region.

There is a positive daily correlation between concentrations of a number of pollution variables and PC 2 and PC9 (Table 10), which represent northern and southern Eurasian centres of variation, respectively (Fig. 1). This implies southeasterly flow from Romania, Bulgaria and Yugoslavia to the site results in enhanced concentrations, as can be seen from the high score composites for these components shown in Fig. 3. PC2 also has significant monthly correlations with sulphate aerosol and sulphur dioxide gas (Table 11). Similarly,

Table 10. K-puszta winter daily partial correlation coefficients. Values in bold are statistically significant at the $5 \%$ level. $n=$ number of cases. Values adjusted for autocorrelation

\begin{tabular}{|c|c|c|c|c|c|c|}
\hline & $\operatorname{lnSO}_{4(\mathrm{aq})}$ & $\operatorname{lnH}^{+}{ }_{(\mathrm{aq})}$ & $\operatorname{lnNH}_{4(a q)}$ & $\operatorname{lnNO} \mathrm{N}_{3(\mathrm{aq})}$ & $\mathrm{InSO}_{2(\mathrm{~g})}$ & $\operatorname{lnSO}_{4(\mathrm{a})}$ \\
\hline PC1 & 0.04 & 0.00 & -0.23 & -0.28 & 0.07 & 0.13 \\
\hline PC2 & 0.24 & -0.03 & -0.03 & 0.27 & 0.28 & 0.07 \\
\hline PC3 & 0.18 & -0.01 & 0.11 & 0.09 & 0.28 & 0.14 \\
\hline PC4 & -0.03 & -0.04 & 0.19 & 0.20 & -0.14 & 0.08 \\
\hline PC5 & -0.19 & -0.05 & -0.06 & -0.01 & -0.11 & -0.14 \\
\hline PC6 & -0.06 & -0.07 & 0.02 & 0.18 & 0.19 & -0.06 \\
\hline PC7 & 0.09 & 0.01 & 0.07 & -0.06 & -0.04 & -0.06 \\
\hline PC 8 & 0.02 & 0.06 & 0.05 & -0.04 & -0.13 & 0.05 \\
\hline PC9 & 0.18 & 0.47 & 0.06 & -0.10 & 0.10 & 0.12 \\
\hline PC10 & 0.23 & -0.06 & 0.20 & 0.03 & -0.02 & 0.04 \\
\hline PC11 & 0.16 & 0.17 & 0.17 & 0.09 & 0.11 & 0.01 \\
\hline PC12 & -0.17 & -0.03 & 0.09 & -0.13 & -0.08 & 0.08 \\
\hline PC 13 & 0.09 & -0.18 & -0.07 & -0.12 & 0.01 & -0.04 \\
\hline PC14 & 0.18 & -0.06 & -0.11 & -0.03 & 0.05 & 0.12 \\
\hline $\mathrm{n}$ & 110 & 50 & 110 & 115 & 50 & 47 \\
\hline
\end{tabular}


Table 11. K-puszta winter monthly partial correlations. Values in bold are statistically significant at the $5 \%$ level. $\mathrm{n}=$ number of cases

\begin{tabular}{|c|c|c|c|c|c|c|}
\hline & $\operatorname{lnSO}_{4(\mathrm{aq})}$ & $\operatorname{lnH}^{+}{ }_{(a q)}$ & $\operatorname{lnNH}_{4(a q)}$ & $\operatorname{lnNO}_{3(a q)}$ & $\mathrm{InSO}_{2(\mathrm{~g}}$ & $\mathrm{InSO}_{4(\mathrm{a})}$ \\
\hline PC1 & 0.27 & -0.28 & -0.27 & 0.12 & 0.42 & 0.42 \\
\hline PC2 & 0.25 & -0.05 & 0.01 & 0.13 & 0.49 & 0.51 \\
\hline PC3 & 0.21 & -0.23 & -0.14 & 0.00 & 0.36 & 0.49 \\
\hline PC4 & -0.40 & -0.28 & 0.03 & -0.13 & -0.27 & -0.26 \\
\hline PC5 & 0.16 & 0.26 & 0.36 & 0.34 & -0.25 & -0.24 \\
\hline PC6 & -0.14 & -0.31 & -0.29 & -0.11 & 0.48 & 0.01 \\
\hline PC7 & 0.07 & 0.13 & 0.05 & 0.11 & -0.13 & -0.14 \\
\hline PC8 & 0.30 & 0.37 & 0.25 & 0.31 & -0.39 & 0.23 \\
\hline PC9 & 0.22 & 0.38 & 0.20 & -0.15 & -0.05 & -0.06 \\
\hline PC 10 & -0.10 & 0.03 & -0.07 & -0.29 & -0.17 & -0.04 \\
\hline PC11 & 0.18 & 0.36 & 0.06 & 0.09 & 0.29 & 0.14 \\
\hline PC 12 & 0.26 & 0.51 & 0.21 & 0.12 & -0.28 & -0.01 \\
\hline PC 13 & $3-0.09$ & -0.23 & -0.59 & -0.29 & 0.51 & 0.17 \\
\hline PC 14 & 0.19 & -0.17 & -0.11 & 0.18 & 0.08 & 0.13 \\
\hline $\mathrm{n}$ & 23 & 15 & 23 & 23 & 22 & 22 \\
\hline
\end{tabular}

the monthly positive relationship between PC 3 and sulphate aerosol (Table 11), and the daily positive relationship between this component and aqueous sulphate and sulphur dioxide gas (Table 10), signifies increased pollutant concentrations with transport from the northeast, from Russia, Poland and the Czech Republic (Figs. $1 \& 3$ ). The physical interpretation behind other statistical associations is not readily apparent; this is probably due to the frequent high pressure and slack pressure gradients over the region (J ones 1997). For example, PC11, centred north of the UK, shows positive daily correlations with aqueous sulphate and ammonium, yet there appears little difference in the pressure patterns around Hungary for high and low score composites (Fig. 3).

\subsection{La Hague}

The only possible pollution sources to the west of this station are the Channel Islands and, to the southwest, Brittany. No data are available for aqueous sulphate concentrations for this site, due to problems of measurements being highly influenced by sea salt concentrations in precipitation (J . Schaug pers. comm.). A change of laboratory occurred in 1989, and as discontinuities in the data were apparent at this point, only data from pre-1989 were used in this analysis. La Hague has the highest concentrations of all the sites, except for K-puszta.

Table 12 indicates that, in common with the other stations, southeasterly flow around the Eurasian winter anticyclone (PC2) (Figs. $1 \& 3$ ) leads to high concentrations of all pollution variables. Other important condi-
Table 12. La Hague winter daily partial correlation coefficients. Values in bold are statistically significant at the $5 \%$ level. $\mathrm{n}=$ number of cases. Values adjusted for autocorrelation

\begin{tabular}{|c|c|c|c|c|c|}
\hline & $\operatorname{lnH}_{(a q)}^{+}$ & $\operatorname{lnNH}_{4(a q)}$ & $\operatorname{lnNO}{ }_{3(a q)}$ & $\operatorname{lnSO}_{2(\mathrm{~g})}$ & $\operatorname{lnSO}_{4(\mathrm{a})}$ \\
\hline PC1 & 0.20 & 0.09 & 0.22 & 0.09 & 0.08 \\
\hline PC2 & 0.17 & 0.19 & 0.25 & 0.21 & 0.39 \\
\hline PC3 & 0.19 & 0.50 & 0.43 & 0.18 & 0.28 \\
\hline PC 4 & 0.11 & 0.12 & 0.04 & -0.23 & -0.12 \\
\hline PC5 & -0.31 & -0.25 & -0.34 & -0.24 & -0.16 \\
\hline PC 6 & 0.00 & 0.08 & -0.08 & -0.09 & -0.12 \\
\hline PC 7 & -0.18 & -0.25 & -0.18 & -0.25 & -0.25 \\
\hline PC 8 & -0.04 & -0.12 & -0.03 & 0.09 & 0.03 \\
\hline PC9 & 0.16 & 0.08 & 0.12 & -0.06 & 0.05 \\
\hline PC 10 & -0.03 & 0.10 & -0.04 & 0.09 & 0.05 \\
\hline PC 11 & 0.13 & 0.11 & 0.08 & 0.13 & 0.08 \\
\hline PC 12 & 0.02 & -0.08 & -0.05 & -0.19 & -0.24 \\
\hline PC13 & 0.08 & 0.06 & 0.03 & 0.09 & 0.07 \\
\hline PC 14 & 0.00 & 0.11 & -0.02 & 0.06 & 0.02 \\
\hline $\mathrm{n}$ & 160 & 170 & 160 & 70 & 72 \\
\hline
\end{tabular}

tions are southerly flow due to low pressure off the northwest coast of Spain (PC5; Figs. $1 \& 3$ ), and northeasterly flow/anticyclonic cover, due to the eastern edge of an anticyclone centred over the UK (PC3; Figs. $1 \& 3$ ). As at Eskdalemuir, sulphur dioxide gas is not significantly related to this component, possibly due to the proximity of both stations to the centre of an anticyclone, thus perhaps with higher reaction rates leading to fast transformation to aqueous and aerosol species.

Two surprising relationships are the negative correlation between PC7 and all pollution variables, and that between PC12 and gas and aerosol data. The low score composites for both (Fig. 3) show westerly and southwesterly flow to the site, a direction which might be expected to be associated with low concentrations.

There are few significant monthly relationships (Table 13). PC2 is related to aqueous hydrogen ion and sulphate aerosol (enhanced southeasterly flow; see above). The relatively strong positive relationship between aqueous nitrate concentrations and PC14 (Fig. 1) is, again, rather surprising since the composite map (Fig. 3) implies the southwest to be a source direction.

\section{DISCUSSION AND CONCLUSIONS}

The work presented in this paper represents the first stage of the development of pollution scenarios for 5 European stations using a climate downscaling methodology. It is necessary firstly to determine the main modes of climate variability over the region under consideration. This has been accomplished using PCA of sea level pressure, for the period 1982 to 1991 . The 
Table 13. La Hague winter monthly partial correlation coefficients. Values in bold are statistically significant at the 5\% level. $\mathrm{n}=$ number of cases.

\begin{tabular}{|lcccrr|}
\hline & $\operatorname{InH}^{+}{ }_{(\mathrm{aq})}$ & $\mathrm{InNH} \mathrm{H}_{\text {(aq) }}$ & $\mathrm{InNO}_{3(\mathrm{aq})}$ & $\mathrm{InSO}_{2(\mathrm{~g})}$ & $\mathrm{InSO}_{4(\mathrm{a})}$ \\
\hline PC1 & 0.37 & 0.13 & 0.19 & -0.03 & -0.19 \\
PC2 & $\mathbf{0 . 5 6}$ & 0.15 & 0.18 & 0.14 & $\mathbf{0 . 5 9}$ \\
PC3 & -0.25 & 0.23 & 0.22 & 0.25 & 0.24 \\
PC4 & -0.08 & 0.12 & 0.08 & -0.01 & -0.03 \\
PC5 & -0.33 & -0.19 & -0.12 & -0.05 & -0.03 \\
PC6 & -0.07 & -0.16 & -0.44 & -0.33 & -0.42 \\
PC7 & 0.20 & -0.35 & -0.28 & 0.05 & -0.06 \\
PC8 & -0.11 & -0.46 & -0.20 & 0.20 & 0.20 \\
PC9 & 0.39 & 0.12 & 0.03 & -0.28 & -0.21 \\
PC10 & -0.15 & 0.35 & 0.24 & 0.18 & -0.12 \\
PC11 & 0.08 & 0.27 & 0.36 & 0.22 & -0.11 \\
PC12 & -0.27 & -0.24 & -0.25 & -0.24 & 0.00 \\
PC13 & -0.07 & -0.01 & -0.06 & -0.09 & -0.22 \\
PC14 & -0.12 & 0.22 & $\mathbf{0 . 4 8}$ & 0.40 & 0.12 \\
n & 16 & 16 & 16 & 16 & 16 \\
\hline
\end{tabular}

construction of composite pressure plots of days with high and low scores for each component allowed investigation of the associated mean pressure patterns. The components were found to adequately represent the regional-scale circulation, since they were interpretable in terms of the known broad-scale circulation features. For example, the first component in all seasons represented the strength of the zonal circulation. Comparisons of the PCA classification with the established manual classification of the LWT, and associations with the 2 climate series of CET and EWR, were physically reasonable. This gave confidence that the PCA classification was an acceptable representation of the regional-scale atmospheric circulation patterns.

The second stage of the analysis was to determine the nature of the relationships between the PCs and the adopted pollution variables at the 5 EMEP monitoring stations. This work confirms the versatility of synoptic climatological methods for the study of pollution, in general, since the links with the PC s were consistent with those in earlier studies and, indeed, gave further insight into the climatological influences on air and precipitation composition at the stations. It should be borne in mind that the pollution climate at a particular station is a function of an assemblage of atmospheric circulations, and so when the combined effect is considered, then the combined level of explanation can be high. Naturally, synoptic climatology will never capture all aspects of transport, transformation and deposition. Reasons for this include, for example, that transformation will partially depend on the particular mix of emissions, affecting factors such as oxidant availability. This in turn may influence factors such as aerosol size, rate of transformation to secondary species, and thus transport.
Regressions have been derived using combinations of PCs, pollution concentrations and precipitation, and the resultant explained variance is up to $80 \%$ ( ones 1997). These relationships are stronger for monthly data, at which time scale the regressions were derived. The UK and central and eastern Europe were found to be pollutant sources for both the Norwegian sites and La Hague. Sources to Eskdalemuir are England and central and eastern Europe. The relationships are less easily interpretable for the Hungarian station, Kpuszta. This is partially due to its less peripheral location, being surrounded by pollution sources. This also highlights a drawback of this methodology: particularly in regions of the domain frequently under the influence of weak pressure gradients, it is relatively difficult to discriminate clear relationships between pollution and particular circulation characteristics. The use of airmass trajectories is a method frequently used to investigate the influence of atmospheric transport on air and precipitation, and this can allow the identification of more definite transport directions (Moody \& Sampson 1989, Dorling et al. 1992). However, weather type or PCA classifications do embrace a much wider selection of the atmospheric conditions which ultimately influence ambient pollution levels (Davies et al. 1991). Whatever classification method is used, a problem associated with using any one particular atmospheric level to determine transport directions is that wind shear and vertical motion cause variations in flow at different atmospheric levels, particularly in the presence of fronts and during precipitation (Kahl 1993). Although results have only been shown for winter here, those for the other 3 seasons show very similar links between particular circulation types and pollution concentrations at the 5 stations (J ones 1997).

An advantage of the method using PCA to investigate links between circulation and air and precipitation chemistry is that the synoptic situation causing a particular flow direction is usually immediately identifiable (with the described occasional exceptions related to anticyclonic conditions in the case of $\mathrm{K}$ puszta, in the south of the domain). The influence of pressure variations in the M editerranean on the pollution climatology of stations as far away as Scandinavia, for example, is one relationship that may not have been expected. This may possibly not have been identified from a smaller domain size which did not include the Mediterranean.

These $\mathrm{PC} /$ pollutant relationships have been used to estimate future deposition using regression relationships (J ones 1997, J ones \& Davies 1998), and global climate model data from the transient integration of the United Kingdom M eteorological Office coupled oceanatmosphere model (UKTR), and will be described in full in a forthcoming paper (J ones \& Davies unpubl.). 
Acknowledgements. J.M.J. is grateful to the School of Environmental Sciences at the University of East Anglia for supporting the research reported in this paper via a research studentship. EMEP are thanked for provision of the chemical data. We would like to acknowledge Dr Hans von Storch, Ricardo Trigo and 3 anonymous reviewers for their helpful suggestions.

\section{LITERATURE CITED}

Alcamo J, Krol M, Posch M (1995) An integrated analysis of sulfur emissions, acid deposition and climate change. Water Air Soil Pollut 85:1539-1550

Amundsen CE, Hanssen J E, Semb A, Steinnes E (1992) Longrange atmospheric transport of trace elements to southern Norway. Atmos Environ 26:1309-1324

Barrow E, Hulme M (1997) Describing the surface climate of the British Isles. In: Hulme M, Barrow E (eds) Climates of the British Isles present, past and future. Routledge, London, p 33-61

Berge E (1988) Time-trends of sulfate and nitrate in precipitation in Norway (1972-1982). Atmos Environ 22:333- 338

Davies TD, Kelly PM, Brimblecombe P, Farmer G, Barthelmie RJ (1986) Acidity of Scottish rainfall influenced by climate change. Nature 322:359-361

Davies TD, Brimblecombe P, Blackwood IL, Tranter M, Abrahams PW (1988) Chemical composition of snow in the remote Scottish Highlands. In: Unsworth $\mathrm{MH}$, Fowler D (eds) Acid deposition at high elevation sites. Kluwer Academic, Dordrecht, p 517-539

Davies TD, Dorling SR, Pierce CE, Barthelmie RJ , Farmer G (1991) The meteorological control on the anthropogenic ion content of precipitation at three sites in the UK; the utility of Lamb Weather Types. Int J Climatol 11:795-807

Davies TD, Pierce CE, Robinson HJ, Dorling SR (1992) Towards an assessment of the influence of climate on wet acidic deposition in Europe. Environ Pollut 75:111-119

Dorling SR (1992) Cluster analysis and the meteorological controls on air and precipitation chemistry in north-west Europe. PhD thesis, University of East Anglia, Norwich

Dorling SR, Davies TD (1995) Extending cluster analysis-synoptic meteorology links to characterise chemical climates at six northwest European monitoring stations. Atmos Environ 29:145-167

Dorling SR, Davies TD, Pierce CE (1992) Cluster analysis: a technique for estimating the synoptic meteorological controls on air and precipitation chemistry - results from Eskdalemuir, S. Scotland. Atmos Environ 26A:2583-2602

Farmer G, Barthelmie RJ , Davies TD, Brimblecombe P, Kelly PM (1987) Relationships between concentration and deposition of nitrate and sulphate in precipitation. Nature 328:787-789

Goodess CM, Palutikof J P (1998) Development of daily rainfall scenarios for southeast Spain using a circulation-type approach to downscaling. Int J Climatol 18:1051-1083

Haagenson PL, Lazrus AL, Ying-Hwa K, Caldwell G (1985) $A$ relationship between acid precipitation and threedimensional transport associated with synoptic-scale cyclones. J Clim Appl Meteorol 24:967-976

Hewitson BC, Crane RG (1992) Regional-scale climate prediction from the GISS GCM. Palaeogeogr Palaeoclimatol Palaeoecol 97:249-267

Hewitson BC, Crane RG (1996) Climate downscaling: techniques and application. Clim Res 7:85-95

Horel J D (1981) A rotated principal components analysis of the interannual variability of the Northern Hemisphere 500mb height field. M on Weather Rev 109:2080-2092

J ohannessen TW (1970) The climate of Scandinavia. In: Wallen CC (ed) World survey of climatology, Vol 5, Climates of northern and western Europe. Elsevier, Amsterdam, p 23-63

J olliffe IT (1982) A note on the use of principal components in regression. Appl Stat 31:300-303

J olliffe IT (1987) Rotation of principal components: some comments. J Climatol 7:507-510

J ones J M (1997) Implications of climate change for acidic deposition over Europe. PhD thesis, University of East Anglia, Norwich

J ones J M, Davies TD (1998) Development of a downscaling methodology for assessment of climate-induced changes in acidic deposition over Europe. In: Proceedings of the European Conference on Applied Climatology, Vienna, 19-23 October 1998. Central Institute for Meteorology and Geodynamics, Vienna

J ones PD (1987) The early twentieth century Arctic highfact or fiction? Clim Dyn 1:63-75

Kahl J D (1993) A cautionary note on the use of air trajectories in interpreting atmospheric chemistry measurements. Atmos Environ 27:3037-3038

Kidson JW (1988) Interannual variations in the southern hemisphere circulation. J Clim 1:1177-1198

Lamb HH (1972) British Isles weather types and a register of the daily sequence of circulation patterns, 1861-1971. Geophysical Memoirs, 116, HMSO, London

Manley G (1974) Central England temperatures: monthly means 1659-1973. Q J R M eteorol Soc 100:389-405

McGregor GR, Bamzelis D (1995) Synoptic typing and its application to the investigation of weather air pollution relationships, Birmingham, United Kingdom. Theor Appl Climatol 51:223-236

Moody J L, Sampson PJ (1989) The influence of atmospheric transport on precipitation chemistry at two sites in the Midwestern United States. Atmos Environ 23:2117-2131

Moody J L, Oltmans SJ, Levy H, Merril JT (1995) Transport climatology of tropospheric ozone: Bermuda, 1988-1991. J Geophys Res 100:7179-7194

North GR, Bell TL, Cahalan RF, Moeng FJ (1982) Sampling errors in the estimation of empirical orthogonal functions. M on Weather Rev 110:699-706

O'Hare GP, Wilby R (1995) A review of ozone pollution in the United Kingdom and Ireland with an analysis using Lamb Weather Types. Geogr J 161:1-20

Pakkanen TA, Hillamo RE, Keronen P, M aenhaut W, Ducasterl G (1996) Sources and physico-chemical characteristics of the atmospheric aerosol in southern Norway. Atmos Environ 30:1391-1405

Parker DE, Legg TP, Folland CK (1992) A new daily Central England Temperature series, 1772-1991. Int J Climatol 12:317-342

Pitovranov SE (1988) The assessment of impacts of possible climate changes on the results of the IIASA RAINS sulfur deposition model in Europe. Water Air Soil Pollut 40: 95-119

RGAR (1990) Acid deposition in the United Kingdom, 1986-1988. The United Kingdom Review Group on Acid Rain. Warren Spring Laboratory, Stevenage

Richman MB (1986) Rotation of principal components. J Climatol 6:293-335

Sanchez ML, Pascual D, Ramos C, Perez I (1990) Forecasting particulate pollutant concentrations in a city from meteorological variables and regional weather patterns. Atmos Environ 24:1509-1519 
Smith FB (1992) Possible future trends in acid rain in the UK. In: Bradshaw AD, Southwood R, Warner F (eds) The treatment and handling of wastes, Chapman and Hall, London, p 105-119

Smith FB, Hunt RD (1978) M eteorological aspects of the transport of pollution over long distances. Atmos Environ 12: 461-477

Villalba R, Cook ER, D'Arrago RD, J acoby GC, J ones PD, Salinger MJ , Palmer J (1997) Sea-level pressure variability around Antarctica since A.D. 1750 inferred from subantarctic tree-ring records. Clim Dyn 13:375-390

von Storch H (1995) Spatial patterns: EOFs and CCA. In: von Storch H, Navarra A (eds) A nalysis of climate variability, applications of statistical techniques. Springer, Berlin, p 227-253

Editorial responsibility: Hans von Storch, Geesthacht, Germany von Storch H, Zwiers FW (1999) Statistical analysis in climate research. Cambridge University Press, Cambridge

Wigley TML (1983) The role of statistics in climate impact analysis. In: Proceedings of the Second International Meeting on Statistical Climatology, Lisbon, 26-30 September 1983, p 8.1.1-8.1.10

Wigley TML, J ones PD (1987) England and Wales precipitation: a discussion of recent changes in variability and an update to 1985. J Climatol 7:231-246

Wilby RL, Wigley TML, Conway D, J ones PD, Hewitson BC, Main J , Wilks DS (1998) Statistical downscaling of general circulation model output: a comparison of methods. Water Resour Res 34:2995-3008

Yarnal B (1993) Synoptic climatology in environmental analysis. Belhaven Press, London

Submitted: J anuary 13, 1999; Accepted: October 9, 1999

Proofs received from author(s): J anuary 12, 2000 